\title{
Phenolic Compounds, Antioxidant and Anti-Cancer Properties of the Australian Maroon Bush Scaevola spinescens (Goodeniaceae)
}

\author{
Quan V Vuong ${ }^{1,2}$, Elham Sadeqzadeh ${ }^{1,2,3}$, Sathira Hirun ${ }^{1,2}$, Chloe D Goldsmith ${ }^{1,2}$, Nicholas Zammitt ${ }^{2}$, Michael C Bowyer ${ }^{1,2}$, Jennette A Sakoff ${ }^{4}$, \\ Rick F Thorne ${ }^{2}$, Judith Weidenhofer ${ }^{3}$ and Christopher J Scarlett ${ }^{1,2,5 *}$
}

${ }^{1}$ Pancreatic Cancer Research, Nutrition Food \& Health Research Group, Australia

${ }^{2}$ School of Environmental and Life Sciences, University of Newcastle, NSW, Australia

${ }^{3}$ School of Biomedical Sciences and Pharmacy, University of Newcastle, NSW, Australia

${ }^{4}$ Department of Medical Oncology, Calvary Mater Newcastle Hospital, Waratah, NSW, Australia

${ }^{5}$ Cancer Research Program, Garvan Institute of Medical Research, Darlinghurst, NSW, Australia

\begin{abstract}
Scaevola spinescens (Goodeniaceae) has been traditionally used by indigenous Australians to treat various ailments including cancer, thus it is necessary to identify optimum extraction conditions for bioactive components from this plant. This study investigated the effects of different extraction conditions on Total Phenolic Content (TPC), antioxidant capacity (ABTS, DPPH, CUPRAC, FRAP assays) and anti-cancer activity (MTT assay) of S. spinescens. The results showed that optimal extraction conditions for TPC using water were $80^{\circ} \mathrm{C}, 15 \mathrm{~min}$ and ratio of $20: 1$ $\mathrm{mL} / \mathrm{g}$. However, the aqueous extract prepared under optimal conditions had lower TPC and less antioxidant capacity than those of the organic solvent extracts. The acetone extract displayed the greatest TPC as well as the highest antioxidant capacity and anti-cancer activity against a panel of cancer cell lines, including cancers of the pancreas, breast, lung, brain, skin, colon and ovary. Therefore, further investigations should be conducted to identify key bioactive compounds as potential anti-cancer agents.
\end{abstract}

Keywords: Scaevola spinescens; Maroon bush tea; Phenolic content; Antioxidant; Anti-cancer

\section{Introduction}

Scaevola spinescens (maroon bush, currant bush, or fanflower) belongs to Goodeniaceae family and is native to Australia. It has been traditionally used by the Aboriginal community for the treatment of various ailments such as colds, stomach-ache, urinary problems, boils, sores and rashes [1]. The first claim for the cancer curing capacity of this plant was reported in 1946 in Western Australia, where a patient claimed that he was cured following continued ingestion of an aqueous extract of the S. spinescens root bark combined with ashes of the desert poplar Codonocarpus cotinifolius [1]. Currently there has been limited research undertaken to elucidate the phytochemical profile and anticancer properties of S. spinescens [2].

The majority of bioactive compounds in plant materials are phenolic compounds [3]. The structural hydroxyl groups within the phenolic compounds results in the capability of these compounds in scavenging reactive oxygen species, such as the superoxide radical, singlet oxygen, hydroxyl radical, nitric oxide, nitrogen dioxide, and peroxynitrite, pertaining to their antioxidant and potential anti-cancer capacities $[4,5]$. Therefore, optimised extraction conditions for the maximum yield of phenolic compounds from $S$. spinescens is essential for ongoing assessment of potential biological and anti-cancer activity.

This study aimed to investigate the impact of extraction conditions on total phenolic content and antioxidant capacity from S. spinescens, and is the first to identify optimal conditions for the increased extraction yield of phenolic compounds from S. spinescens. In addition, the anticancer effects of $S$. spinescens extracts were tested against numerous cancer cell lines in vitro, providing strong preliminary evidence for further assessment of the putative anti-cancer activity of $S$. spinescens.

\section{Materials and Methods}

\section{Plant material}

Scaevola spinescens (Goodeniaceae) (SC) was donated by Jeanie
Crago (Outback Books Australia; and commercial supplier of Maroon bush tea sold in ground-dried form). Dried and harvested SC was packed in PE bags and stored in freezer at $-18^{\circ} \mathrm{C}$ until required.

\section{Experimental design}

SC has been traditionally prepared by brewing in water, with the decoction consumed like tea. The current study determined the impact of aqueous extraction conditions (including temperature, time and water-to-SC ratio) on extraction efficiency of Total Phenolic Compounds (TPC), and optimized these extraction conditions to maximize the extraction yield of TPC. In addition, three organic solvents of high to modest polarity were used to extract TPC. SC was extracted in acetone, methanol or ethanol at the ratio of $20: 1 \mathrm{~mL} / \mathrm{g}$ and agitated at room temperature (RT) for $72 \mathrm{~h}$. The solutions were then filtered twice using $11 \mu \mathrm{m}$ medium filter paper (Lomb Scientific, Taren Point, NSW, Australia), and concentrated under reduced pressure at $45^{\circ} \mathrm{C}$ (Buchi Rotavapor B-480, Buchi Australia, Noble Park, Vic., Australia). The concentrated extract was then dried using a FD3 freeze drier (Thomas Australia Pty. Ltd., Seven Hills, NSW, Australia) at $-40^{\circ} \mathrm{C}$ for $48 \mathrm{~h}$ and the resulting crude powdered extracts then stored at $-18^{\circ} \mathrm{C}$ until required. The extraction scheme is illustrated in Figure 1.

${ }^{*}$ Corresponding author: Christopher J. Scarlett, Head, Pancreatic Cance Research Nutrition Food and Health Research Group, University of Newcastle, Brush Rd, Ourimbah, NSW 2258, Australia. Tel: +61 243484680 ; Fax: +61 24348 4145; E-mail: c.scarlett@newcastle.edu.au

Received October 06, 2014; Accepted November 25, 2014; Published Novembe 28, 2014

Citation: Vuong QV, Sadeqzadeh E, Hirun S, Goldsmith CD, Zammitt N, et al (2014) Phenolic Compounds, Antioxidant and Anti-Cancer Properties of the Australian Maroon Bush Scaevola spinescens (Goodeniaceae). J Bioanal Biomed S12: 002. doi:10.4172/1948-593X.S12-002

Copyright: ( 2014 Vuong QV, et al. This is an open-access article distributed under the terms of the Creative Commons Attribution License, which permits unrestricted use, distribution, and reproduction in any medium, provided the original author and source are credited. 


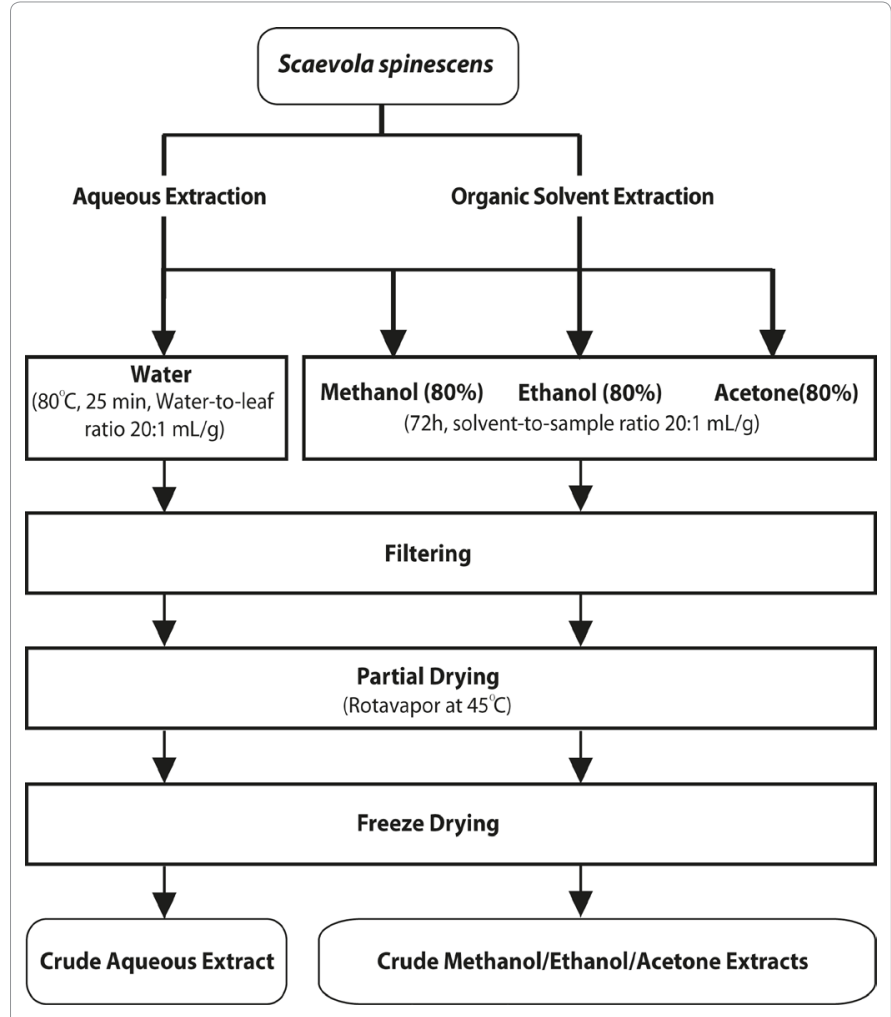

Figure 1: Preparation flowchart of aqueous and organic solvent extracts from SC.

\begin{tabular}{|c|c|c|c|c|}
\hline \multirow{2}{*}{ Runs } & \multicolumn{3}{|c|}{ Box-Behnken design } & Actual observed \\
\cline { 2 - 5 } & $\begin{array}{c}\text { Temperature } \\
\left({ }^{\circ} \mathbf{C}\right)\end{array}$ & $\begin{array}{c}\text { Time } \\
(\mathbf{m i n})\end{array}$ & $\begin{array}{c}\text { Ratio } \\
(\mathbf{m L} / \mathbf{g})\end{array}$ & $\begin{array}{c}\text { Extraction yield } \\
(\mathbf{m g} \text { GAE/g) }\end{array}$ \\
\hline 1 & 70 & 5 & $55: 1$ & 11.73 \\
\hline 2 & 70 & 15 & $10: 1$ & 11.57 \\
\hline 3 & 70 & 25 & $55: 1$ & 13.88 \\
\hline 4 & 70 & 15 & $100: 1$ & 12.63 \\
\hline 5 & 80 & 25 & $10: 1$ & 13.06 \\
\hline 6 & 80 & 15 & $55: 1$ & 16.85 \\
\hline 7 & 80 & 5 & $10: 1$ & 9.39 \\
\hline 8 & 80 & 15 & $55: 1$ & 16.21 \\
\hline 9 & 80 & 25 & $100: 1$ & 13.40 \\
\hline 10 & 80 & 15 & $55: 1$ & 19.88 \\
\hline 11 & 80 & 5 & $100: 1$ & 15.68 \\
\hline 12 & 90 & 15 & $10: 1$ & 12.50 \\
\hline 13 & 90 & 25 & $55: 1$ & 15.63 \\
\hline 14 & 90 & 15 & $100: 1$ & 17.37 \\
\hline 15 & 90 & 5 & $55: 1$ & 15.12 \\
\hline
\end{tabular}

Table 1: Box-Behnken design by RSM and the responses observed.

To determine the effect of temperature, time and water-to-SC ratio on aqueous TPC extraction from SC, Response Surface Methodology (RSM) utilising a Box-Behnken design, was employed (Table 1). To express the content of TPC as a function of the independent variables, the following second-order polynomial equation was used [6] (EQ1):

$$
Y=\beta_{o}+\sum_{i=1}^{k} \beta_{i} X_{i}+\sum_{\substack{i=1 \\ i<j}}^{k-1} \sum_{j=2}^{k} \beta_{i j} X_{i} X_{j}+\sum_{i=1}^{k} \beta_{i i} X_{i}^{2}
$$

Where various $\mathrm{X}_{\mathrm{i}}$ values are independent variables affecting the responses $Y ; \beta_{0}, \beta_{\mathrm{i}}, \beta_{\mathrm{ii}}$, and $\beta_{\mathrm{ij}}$ are the regression coefficients for intercept, linear, quadratic, and interaction terms, respectively; and $\mathrm{k}$ is the number of variables.

\section{Determination of total phenolic compounds}

TPC were determined using the modified method of Vuong et al. [7]. Briefly, a $1 \mathrm{~mL}$ aliquot of each sample $(400 \mu \mathrm{g} / \mathrm{mL})$ was added with 5 $\mathrm{mL}$ of $10 \%(\mathrm{v} / \mathrm{v})$ Folin-Ciocalteu reagent and left at room temperature (RT) for $5 \mathrm{~min}$ before mixing with $4 \mathrm{~mL}$ of $\mathrm{Na}_{2} \mathrm{CO}_{3}(7.5 \% \mathrm{w} / \mathrm{v})$ and then incubated in the dark at RT for $60 \mathrm{~min}$. Absorbance was measured at $760 \mathrm{~nm}$ with Gallic Acid (GA) used as a standard. TPC were expressed as mg Gallic Acid Equivalents (GAE) per gram of extract (mg GAE/g).

\section{Determination of antioxidant capacity}

Four antioxidant assays (ABTS, DPPH, CUPRAC and FRAP) were employed to determine the antioxidant capacity of the crude SC extracts. The SC extracts were dissolved in $70 \%$ methanol to give final concentrations of 50,100, 200 and $400 \mu \mathrm{g} / \mathrm{mL}$ for subsequent analysis. For comparison with antioxidant capacity of SC extracts at concentration of $200 \mu \mathrm{g} / \mathrm{mL}$, three known antioxidants including a-tocopherol (90\% purity), BHT (99\% purity) and ascorbic acid (95\% purity) were also prepared at concentration of $200 \mu \mathrm{g} / \mathrm{mL}$. The results were expressed as $\mu \mathrm{M}$ of Trolox equivalents per litre $(\mu \mathrm{M} \mathrm{TE} / \mathrm{L})$ for the ABTS and DPPH assays, and $\mu \mathrm{M}$ of Trolox equipvalents per gram of the extract ( $\mu \mathrm{M} \mathrm{TE} / \mathrm{g})$ for the CUPRAC and FRAP assays.

ABTS: To determine total antioxidant capacity using the ABTS assay, we employed a modified method of Thaipong et al. [8]. A stock solution was prepared by mixing $1: 1$ of $7.4 \mathrm{mM} \mathrm{ABTS}^{-+}$and $2.6 \mathrm{mM}$ potassium persulfate solution and left to incubate for $12 \mathrm{~h}$ at RT in the dark. A working solution was prepared fresh by mixing $1 \mathrm{~mL}$ of stock solution in $60 \mathrm{~mL}$ methanol to obtain an absorbance of $1.1 \pm 0.02$ at $734 \mathrm{~nm}$. The extracts $(150 \mathrm{~mL})$ were then mixed with $2850 \mathrm{~mL}$ of the working solution for $2 \mathrm{~h}$ in the dark (RT) and the absorbance was read at $734 \mathrm{~nm}$.

DPPH: The DPPH method, as described by Vuong et al. [7], was used to determine free radical scavenging capacity of the SC extracts. A stock solution of $0.024 \%(\mathrm{w} / \mathrm{v})$ DPPH in methanol was prepared and stored at $-18^{\circ} \mathrm{C}$ until use. The working solution was freshly prepared by diluting $10 \mathrm{~mL}$ of stock solution with $45 \mathrm{~mL}$ of methanol to obtain an absorbance of $1.1 \pm 0.02$ at $515 \mathrm{~nm} .0 .2 \mathrm{~mL}$ of the sample was then mixed with $3.8 \mathrm{~mL}$ of working solution and incubated in the dark for 3 hours (RT) before measuring the absorbance at $515 \mathrm{~nm}$.

CUPRAC: A modified method of Apak et al. [9] was employed to determine the cupric ion reducing antioxidant capacity of the SC extracts. $1 \mathrm{~mL}$ of $10 \mathrm{mM} \mathrm{CuCl}_{2}$ was mixed with $1 \mathrm{~mL}$ of $7.5 \mathrm{mM}$ neocuproine and $1 \mathrm{~mL}$ of $7.7 \%(\mathrm{w} / \mathrm{v}) \mathrm{NH}_{4}$ Ac. Then $1.1 \mathrm{~mL}$ of the diluted sample was added and incubated at RT for $1.5 \mathrm{~h}$ before measuring the absorbance at $450 \mathrm{~nm}$.

FRAP: The method described by Thaipong et al. [8] with some modifications was used to determine the ferric reducing antioxidant power of the SC extracts. Reagent A included $300 \mathrm{mM}$ acetate buffer (3.1 $\mathrm{g} \mathrm{C}_{2} \mathrm{H}_{3} \mathrm{NaO}_{2} \cdot 3 \mathrm{H}_{2} \mathrm{O}$ and $16 \mathrm{~mL} \mathrm{C}_{2} \mathrm{H}_{4} \mathrm{O}_{2}$, diluted to $1000 \mathrm{~mL}$ with $\mathrm{H}_{2} \mathrm{O}$ ), pH 3.6; Reagent B included 10mM TPTZ (2, 4, 6-tripyridyl-s -triazine) solution in $40 \mathrm{mM} \mathrm{HCl}$; and Reagent $\mathrm{C}$ was $20 \mathrm{mM}$ $\mathrm{FeCl}_{3} \bullet 6 \mathrm{H}_{2} \mathrm{O}$ solution. The fresh FRAP solution was prepared by mixing Reagents A, B and C at the ratio of 10:1:1. The extract $(150 \mu \mathrm{L})$ was then mixed with $2850 \mu \mathrm{L}$ of the FRAP solution and incubated at RT for 30 min in the dark. Absorbance was then measured at $593 \mathrm{~nm}$. 


\section{Assessment of growth inhibition of crude SC extracts on cancer cell lines}

Human cancer cell lines were obtained from the American Type Culture Collection (ATCC, Manassas, VA, USA). The cytotoxicity of the crude SC extracts was screened using the 3-(4,5-dimethylthiazol-2yl)-2,5-diphenyltetrazolium bromide (MTT) assay to quantify cancer cell growth inhibition as previously described [10]. The cell line panel consisted of HT29 (colon); U87, SJ-G2, SMA (glioblastoma); MCF-7 (breast); A2780 (ovarian); H460 (lung); A431 (skin); Du145 (prostate); $\mathrm{BE} 2-\mathrm{C}$ (neuroblastoma); and MiaPaCa-2 (pancreas) together with the one non-tumour derived normal breast cell line (MCF10A). Briefly, all cancer cell lines were cultured in Dulbecco's Modified Eagle Medium (DMEM) supplemented with 10\% foetal bovine serum, 50IU/ $\mathrm{ml}$ penicillin, $50 \mathrm{ug} / \mathrm{ml}$ streptomycin and $2 \mathrm{mM}$ L-glutamine. The MCF10A cells were cultured in DMEM:F12 (1:1) cell culture media, $5 \%$ heat inactivated horse serum, supplemented with penicillin (50 IU/ $\mathrm{mL})$, streptomycin $(50 \mu \mathrm{g} / \mathrm{mL}), 20 \mathrm{mM}$ Hepes, L-glutamine $(2 \mathrm{mM})$, epidermal growth factor $(20 \mathrm{ng} / \mathrm{ml})$, hydrocortisone $(500 \mathrm{ng} / \mathrm{ml})$, cholera toxin $(100 \mathrm{ng} / \mathrm{ml})$, and insulin $(10 \mathrm{ug} / \mathrm{ml})$. Cells were plated in triplicate in DMEM $(100 \mu \mathrm{L})$ in a 96 well plate, at densities of 2500 - 4000 cells per well optimized to achieve logarithmic growth after 24 hours. The following day, $100 \mu \mathrm{L}$ of media containing dissolved crude SC extract was added to each well to give the final concentration of $100 \mu \mathrm{g} / \mathrm{mL}$, along with media only as controls. To quantify cell growth inhibition across the panel of cancer and non-cancer cell lines the cytotoxicity of the crude SC extracts was measured after $72 \mathrm{hrs}$ of incubation using the MTT assay as per the manufacturer's instructions [10]. The absorbance was read at $540 \mathrm{~nm}$ to determine growth inhibition after 72 hours of incubation based on the difference in the optical density values on day 0 versus those at the end of SC extract exposure. Cell growth inhibition as a percentage was determined, where a value of $100 \%$ is indicative of total growth inhibition. An eight-point dose response curve $(0.5 \mu \mathrm{g} / \mathrm{mL}-200 \mu \mathrm{g} / \mathrm{mL})$ was also produced, from which a value was obtained representing the SC concentration that induced $50 \%$ growth inhibition.

\section{Statistical analysis}

Response Surface Methodology (RSM) experimental design and analysis were conducted using JMP software (Version 10). The software was also used to establish the model equation, to graph the 3-D plot, 2-D contour of the response and to predict the optimum values for the three response variables. The one-way ANOVA and the LSD posthoc test were conducted to assess mean differences of TPC levels and antioxidant capacity between extracts using the SPSS statistical software (Version 20). Antioxidant capacity data are represented as mean \pm standard deviations for triplicate experiments. Differences between the mean levels of the components in different experiments were taken to be statistically significant at $\mathrm{p}<0.05$.

\section{Results and Discussion}

\section{Impact of aqueous extraction conditions on TPC}

Response Surface Methodology (RSM) has the advantage of comparing numerous influential variables in minimal time, while also identifying interactions between extraction parameters. To determine the effect of temperature, time and water-to-SC ratio on aqueous TPC extraction from SC, response surface methodology (RSM) utilising a Box-Behnken design was employed using a range of extraction conditions (temperature, $70-90^{\circ} \mathrm{C}$; time, $5-25 \mathrm{~min}$; and water-to-SC ratio, 100:1 - 100:10 $\mathrm{mL} / \mathrm{g}$; (Table 1). The resulting yields were then fitted to the Box-Behnken design model [11] and analysed using multiple regression and response surface analysis to fit the generated second-order polynomial equation for temperature (A), time (B) and ratio $(\mathrm{C})$. The predictive equation for response TPC (Y) was as follows (EQ2):

$\mathrm{Y}=-96.730+2.415 \mathrm{~A}+1.149 \mathrm{~B}+0.205 \mathrm{C}-0.0146 \mathrm{~A}^{2}-0.021 \mathrm{~B}^{2}-$ $0.0013 \mathrm{C}^{2}+0.0041 \mathrm{AB}+0.02 \mathrm{AC}-0.0033 \mathrm{BC}(\mathrm{EQ} 2)$.

The overall statistical analysis (Table 2) showed that the coefficient of determination $\left(\mathrm{R}^{2}\right)$ was approximately 0.92 , revealing that a total of $92 \%$ of the variation in TPC could be explained. In addition, the statistical analysis also showed that the lack of fit for TPC was nonsignificant $(\mathrm{p}=0.99)$. The findings revealed that the second-order polynomial model adequately represented the true response of the system, thus the model is appropriate for predicting the experimental outcome. Within the experimental conditions used, the extraction efficiency of TPC was shown to closely correlate with temperature (A) and ratio $(\mathrm{C})(\mathrm{p}<0.05)$ in the first-order linear effect (Table 2). TPC were also found to have high correlations with second-order quadratic effect for time $\times$ time $\left(B^{2}\right)$ and ratio $\times$ ratio $\left(C^{2}\right)(p<0.05)$. However, these correlations were not significant for the extraction time (B), interactive effects $(\mathrm{AB}, \mathrm{AC}$ and $\mathrm{BC})$, or temperature $\times$ temperature $\left(\mathrm{A}^{2}\right)$ ( $\mathrm{p}>0.05)$ (Table 2).

Based on probability from the largest to the smallest effect on TPC from the statistical analysis (Table 2), the water-to-SC ratio (C) had the biggest influence on the extraction of TPC, followed by temperature (A) and extraction time (B). The impact of these three independent variables was further explained in Figure 2. These data showed that TPC was predicted to increase significantly when temperatures increased from 70 to $90^{\circ} \mathrm{C}$. This can be explained by the increase of mass transfer rates during extraction and also the corruption of the cell walls caused by heat thus more TPC can be released into the solvent [12].In addition, (Figure 2) showed that TPC was predicted to increase when the time increased to $15 \mathrm{~min}$; however, levels of TPC were predicted to decrease when extraction time exceeded $15 \mathrm{~min}$. This can be explained by the degradation of TPC when over-exposed to high temperatures. The TPC was also predicted to increase when the ratio of water-to-sample increased. This can be explained by acceleration of extraction kinetics observed when increasing the volume of solvent, which leads to greater concentration gradients existing between phenolics trapped inside the particles and those located at the surface [12].

\section{Optimisation of aqueous extraction conditions for increased TPC}

The Indigenous Australian community has traditionally prepared

\begin{tabular}{|l|c|c|c|}
\hline Source & $\begin{array}{c}\text { Degree of } \\
\text { Freedom }\end{array}$ & F-ratio & Probability > F \\
\hline A (Temperature) & 1 & 9.1573 & $0.0292^{*}$ \\
\hline B (Time) & 1 & 1.283 & 0.3087 \\
\hline C (Water-Sample Ratio) & 1 & 12.3903 & $0.0169^{*}$ \\
\hline AB & 1 & 0.4238 & 0.5438 \\
\hline AC & 1 & 2.2893 & 0.1907 \\
\hline CB & 1 & 5.5602 & 0.0649 \\
\hline$A^{2}$ & 1 & 4.9485 & 0.0767 \\
\hline$B^{2}$ & 1 & 10.181 & $0.0242^{*}$ \\
\hline$C^{2}$ & 1 & 16.4777 & $0.0097^{*}$ \\
\hline P value of lack of fit $^{2}$ & & & 0.9929 \\
\hline$R^{2}$ & & & 0.9246 \\
\hline
\end{tabular}

Table 2: Statistical analysis of regression 


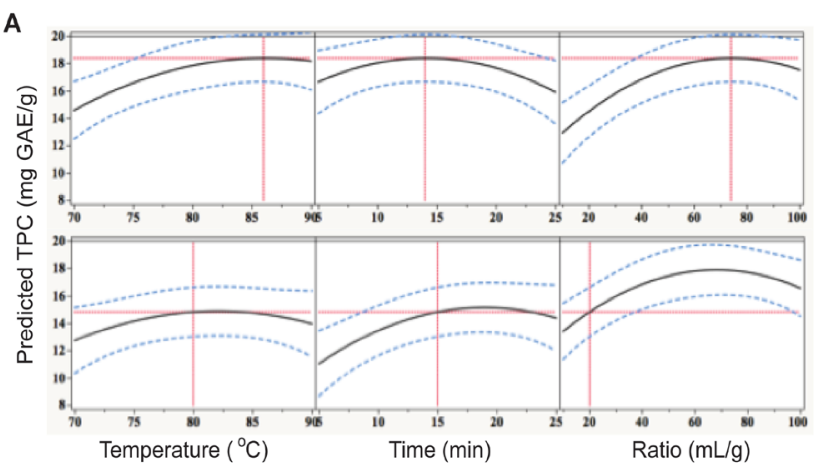

B

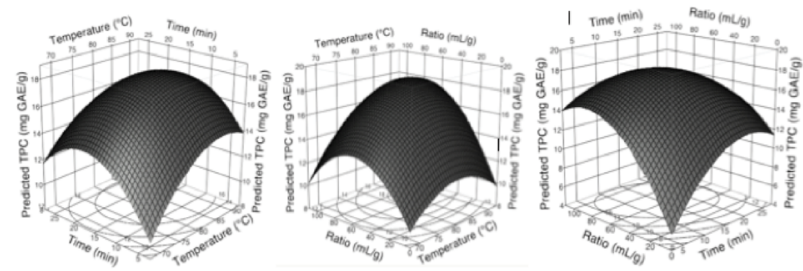

Figure 2: (A) Impact of extraction conditions on total phenolic compounds. (B) The 3D response surface and 2D contour plots of total polyphenols affected by extraction temperature, time and ratio.

the SC decoction by brewing in water; however the methods of preparation in this context are uncertain. This study revealed that aqueous extraction conditions significantly affected extraction efficiency of TPC; consequently, their effects on potential health applications could also be significantly influenced. Therefore, it was necessary to optimize the conditions for aqueous extraction of to yield greater levels of TPC from SC.

The maximum value of TPC ( $18.37 \mathrm{mg} \mathrm{GAE} / \mathrm{g})$ was predicted to be achieved when $\mathrm{SC}$ was extracted at $86^{\circ} \mathrm{C}, 14 \mathrm{~min}$ and a water-to-SC ratio of $74: 1 \mathrm{~mL} / \mathrm{g}$. However, there are questions as to whether these TPC levels can be retained when reducing the water-to-SC ratio, as a higher volume of water has higher energy requirements, both in heating the solvent during extraction and subsequent removal post-extraction [7]. Therefore, the extraction conditions were adjusted to $80^{\circ} \mathrm{C}, 15 \mathrm{~min}$. and a water-to-SC ratio of $20: 1 \mathrm{~mL} / \mathrm{g}$ based on the predictive model. Under these conditions (lower temperature and $75 \%$ less water required for the extraction) it was predicted that approximately $14.81 \mathrm{mg} \mathrm{GAE} / \mathrm{g}$ could be extracted, indicating that $81 \%$ of TPC could be retained when compared to the high energy conditions of $86^{\circ} \mathrm{C}, 14 \mathrm{~min}$ and ratio of $74: 1 \mathrm{~mL} / \mathrm{g}$. These conditions $\left(80^{\circ} \mathrm{C}, 15 \mathrm{~min}\right.$ and ratio of $\left.20: 1 \mathrm{~mL} / \mathrm{g}\right)$ were therefore selected as optimal conditions for the subsequent validation experiments.

Validation experiments $(n=6)$ revealed that there was no significant difference between the predicted TPC value $(14.81 \pm 1.80 \mathrm{mg} \mathrm{GAE} / \mathrm{g})$ obtained by RSM, and the actual measured TPC value $(13.16 \pm 0.68$ $\mathrm{mg}$ GAE/g; $>>0.05$ ). Thus the optimal conditions for the aqueous extraction of TPC from SC were confirmed to be $80^{\circ} \mathrm{C}, 15 \mathrm{~min}$, and a water-to-SC ratio of $20: 1 \mathrm{~mL} / \mathrm{g}$, and these conditions were used for further preparation of crude TPC-enriched SC extracts.

\section{Impact of extraction solvents on TPC}

Water is safe, cheap and accessible; however, its use is only limited to the extraction of highly polar organic compounds. Furthermore, water has a significantly greater dielectric constant $(\varepsilon)\left(\mathrm{H}_{2} \mathrm{O}, \varepsilon=80\right)$ in comparison to other common organic solvents such as methanol ( $\varepsilon=33)$, acetone $(\varepsilon=21)$ and ethanol $(\varepsilon=24.55)$ [7]. In addition, Michiels et al. [13] reported that phenolic content and antioxidant activities were affected when using various organic solvents due to their different polarities. As such, it is necessary to examine the applicability of different solvents on TPC yields and activity. Besides water, the organic solvents have been commonly used for extraction of phenolic contents from fresh products including: methanol, ethanol, acetone, propanol and/or ethyl acetate [14]. Therefore, this study examined the effects of four solvents: water, methanol, ethanol and acetone on extraction of TPC from SC and the results presented in Figure 3.

Solvent character influenced the extraction efficiency of TPC. Organic solvents possessed significantly higher extraction efficiency for TPC in comparison with aqueous extraction $(68.3 \%, 53.65 \mathrm{mg}$ $\mathrm{GAE} / \mathrm{g})$. Among the tested organic solvents, acetone (78.58 mg GAE/g) exhibited the highest extraction efficiency, followed by methanol and ethanol, which accounted for $89.2 \%$ (70.1 mg GAE/g) and $86.5 \%$ (68.0 mg GAE/g), respectively, of TPC extracted by acetone. Extraction efficiencies was found to correlate closely to solvent polarity and are consistent with previously published studies examining solvent effects on TPC extracts from papaya leaves (Carica L.) [7], ginkgo leaves (Ginkgo biloba L.) [15] and henna stems (Lawsonia inermis) [16]. In summary, the current findings indicated that solvents with different polarities significantly affected extraction efficiency of TPC, and organic solvents extracted higher TPC than water and among the tested organic solvents, acetone is the best solvent to extract TPC from SC.

\section{Impact of extraction solvents on antioxidant activity}

Total antioxidant capacity: The Total Antioxidant Capacity (TAC) is a relevant tool for identifying the relationship between dietary antioxidants and pathologies induced by oxidative stress. TAC of the antioxidants was measured using ABTS assay, which was based on the antioxidant reaction with an organic cation radical [17]. Figure 4A showed TAC was not significantly different among the organic solvents at a concentration of $200 \mu \mathrm{g} / \mathrm{mL}(\mathrm{p}<0.05)$. However, the organic solvent extracts had higher TAC in comparison with aqueous extract. At the same concentration $(200 \mu \mathrm{g} / \mathrm{mL})$, organic and aqueous extracts of SC exhibited lower TAC in comparison with those of pure $\alpha$-Tocopherol, ascorbic acid and BHT.

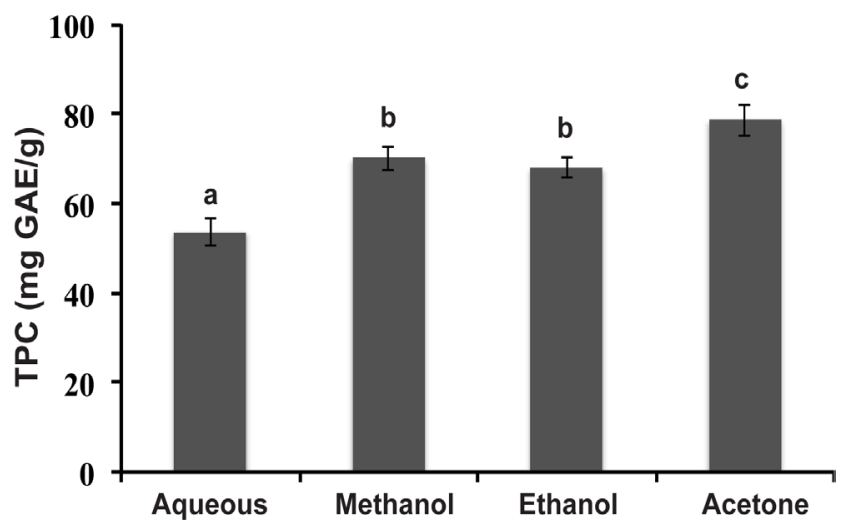

Figure 3: Total phenolic content of the SC extracts. The values are mean \pm standard deviations for triplicate experiments and those not sharing a letter on top of the columns are significantly different at $p<0.05$. 
Figure $4 \mathrm{~B}$ indicated that $\mathrm{TAC}$ of organic and aqueous extracts responded in a dose dependent manner as TAC increased when concentrations of the extracts increased ( 50 to $400 \mu \mathrm{g} / \mathrm{mL}$ ). Based on the linear regression slopes, acetone was found to have stronger TAC, followed by methanol, ethanol and water. TAC broadly correlates with the TPC extract yields in terms of solvent polarity. While the more polar solvent $\mathrm{MeOH}$ showed a slightly higher average TAC yield, the figure was not significantly different from EtOH. This result again reflects the general preference for phenolics and other natural reducing agents to partition efficiently in solvents of intermediate polarity. Based on these data, acetone is thus the solvent of choice for obtaining an extract with optimal total antioxidant capacity.

DPPH free radical scavenging capacity: Free radical scavenging
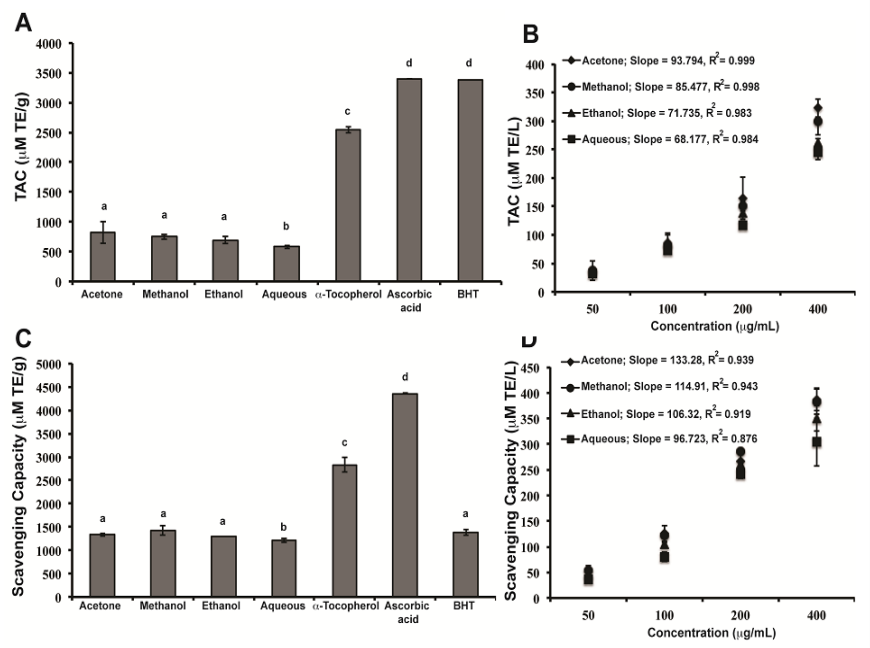

Figure 4: Antioxidant and free radical scavenging capacity of the SC extracts using the ABTS (A, B) and DPPH (C, D) assays in comparison to $\alpha$-tocopherol, ascorbic acid and BHT, at a concentration of $200 \mu \mathrm{g} / \mathrm{mL}$. The values are mean \pm standard deviations for triplicate experiments and those not sharing a letter on top of the columns are significantly different at $p<0.05$.

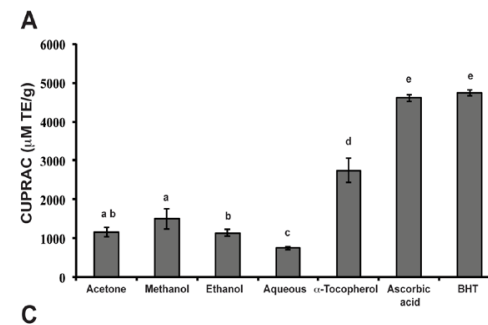

7000 Actone: Slope $=135.99 . R^{2}=0.997$

- Methanol: Slope $=154.59 \cdot R^{2}=0.997$
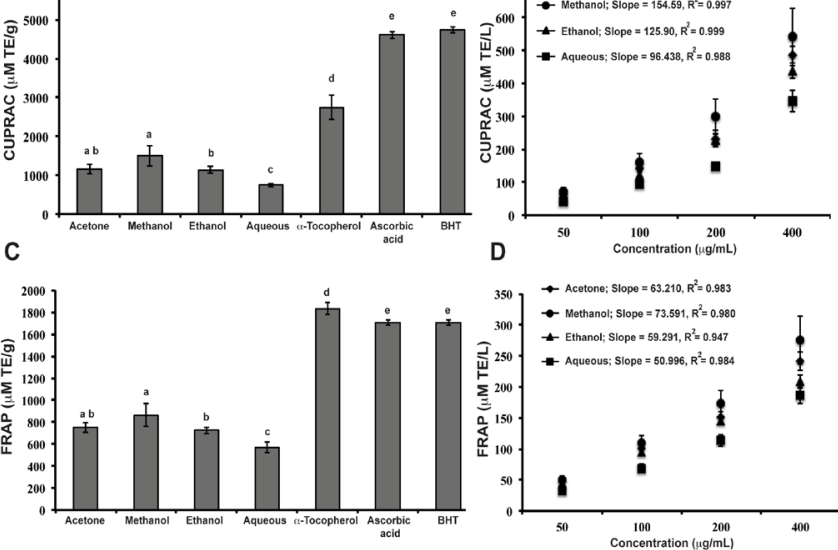

Figure 5: Ion reducing capacity of the SC extracts using the CUPRAC (A, B) and FRAP (C, D) assays in comparison to a-tocopherol, ascorbic acid and BHT, at a concentration of $200 \mu \mathrm{g} / \mathrm{mL}$. The values are mean \pm standard deviations for triplicate experiments and those not sharing a letter on top of the columns are significantly different at $p<0.05$. capacity was measured using the DPPH assay, which was based on the antioxidant reaction with 2,2-diphenyl-1-picrylhydrazyl, which forms a stable radical scavenger in solution [17]. Figure 4C showed that at the concentration of $200 \mu \mathrm{g} / \mathrm{mL}$, acetone, ethanol and methanol extracts had similar free radical scavenging capacities that were significantly higher than the aqueous extract $(\mathrm{p}<0.05)$. At this concentration of 200 $\mu \mathrm{g} / \mathrm{mL}$, the organic solvent extracts had similar scavenging capacity to high purity BHT and accounted for $50 \%$ and $30 \%$ of pure $\alpha$-Tocopherol and ascorbic acid respectively.

Figure $4 \mathrm{D}$ revealed that the free radical scavenging capacity of SC extracts increased when their concentrations rose from 50 to $400 \mu \mathrm{g} /$ $\mathrm{mL}$, indicating that free radical scavenging of SC was dose dependent. The linear regression showed that acetone would possess stronger free radical scavenging capacity than other solvents if higher concentrations of the extracts were applied. Thus, acetone is also the solvent of choice for obtaining extract with high free radical scavenging capacity.

Cupric Reducing Antioxidant Capacity (CUPRAC): The principle of the CUPRAC assay is to assess the reducing capacity of the antioxidants through their action of donating electrons to reduce $\mathrm{Cu}$ (II) to $\mathrm{Cu}$ (I). The higher CUPRAC value is linked with higher reducing power of the antioxidant extract [17]. Our data (Figures $5 \mathrm{~A} \& \mathrm{~B}$ ) revealed that the CUPRAC capacity of acetone extract was not significantly different to that of the methanol extract, but was significantly higher than that of ethanol extract at concentration of 200 $\mu \mathrm{g} / \mathrm{mL}$. CUPRAC for the aqueous extract was significantly lower than the organic extracts and concentrations $>100 \mu \mathrm{g} / \mathrm{mL}$. In comparison with high purity $a$-Tocopherol, ascorbic acid and BHT at the same concentration $(200 \mu \mathrm{g} / \mathrm{mL})$, the SC extracts exhibited uniformly lower CUPRAC capacity, accounting for approximately half of the activity of a-Tocopherol and a third of ascorbic acid or BHT.

Ferric Reducing Antioxidant Power (FRAP): The FRAP (ferric reducing antioxidant power) was measured using the FRAP assay based on the reduction of potassium ferricyanide by antioxidants and subsequent reaction of potassium ferrocyanide with $\mathrm{Fe}^{3+}$. The FRAP value increase can be correlated to the reducing ability of antioxidants/ antioxidant extracts [17]. At $200 \mu \mathrm{g} / \mathrm{mL}$, the acetone extract exhibited the highest FRAP, followed by methanol, ethanol and the aqueous extract (Figure 5A and 5B). SC extracts also had lower FRAP than those of $\alpha$-Tocopherol, ascorbic acid and BHT at the same concentration $(200 \mu \mathrm{g} / \mathrm{mL})$ (Figure 5C).

Figure 5D further confirmed that FRAP of SC extracts were dose dependent, and based on the slopes of linear regression, the order of FRAP was acetone, followed by methanol, ethanol then the aqueous extract.

Correlation between total phenolic compounds and antioxidant properties: The correlation between the total phenolic content and antioxidant capacity of the extracts were assessed, with the results shown in Table 3. We revealed that the antioxidant properties of SC had a positive correlation with TPC. Based on the $\mathrm{R}^{2}$ values, ABTS antioxidant capacity had the highest correlation with TPC $\left(\mathrm{R}^{2}=0.85\right)$, followed by DPPH free radical scavenging capacity $\left(\mathrm{R}^{2}=0.81\right)$, CUPRAC

\begin{tabular}{|l|c|}
\hline Antioxidant property & R - Square \\
\hline Total antioxidant capacity & 0.85 \\
\hline DPPH free radical scavenging capacity & 0.81 \\
\hline Cupric reducing antioxidant capacity & 0.79 \\
\hline Ferric reducing antioxidant power & 0.71 \\
\hline
\end{tabular}

Table 3: Linear correlation of antioxidant capacity with total phenolic content. 
Citation: Vuong QV, Sadeqzadeh E, Hirun S, Goldsmith CD, Zammitt N, et al. (2014) Phenolic Compounds, Antioxidant and Anti-Cancer Properties of the Australian Maroon Bush Scaevola spinescens (Goodeniaceae). J Bioanal Biomed S12: 002. doi:10.4172/1948-593X.S12-002

\begin{tabular}{|c|c|c|c|c|c|c|}
\hline \multirow{2}{*}{ Cell Line } & \multirow{2}{*}{ Cancer Cell Type } & \multicolumn{5}{|c|}{ S. spinescens extract } \\
\hline & & Aqueous $^{a}$ & Methanol $^{a}$ & Ethanol $^{\mathrm{a}}$ & Acetone $^{a}$ & Acetone $\mathrm{Gl}_{50}{ }^{\mathrm{b}}$ \\
\hline HT29 & Colon & $19 \pm 3$ & $52 \pm 3$ & $29 \pm 2$ & $80 \pm 5$ & $65 \pm 5.8$ \\
\hline U87 & Glioblastoma & $26 \pm 13$ & $34 \pm 5$ & $22 \pm 3$ & $41 \pm 3$ & $110 \pm 13$ \\
\hline SJ-G2 & Glioblastoma & $30 \pm 4$ & $52 \pm 4$ & $54 \pm 7$ & $83 \pm 4$ & $20 \pm 9.5$ \\
\hline SMA & Glioblastoma (Murine) & $25 \pm 6$ & $42 \pm 3$ & $33 \pm 0.2$ & $80 \pm 1$ & $49 \pm 3.5$ \\
\hline MCF-7 & Breast & $44 \pm 8$ & $68 \pm 4$ & $65 \pm 1$ & $82 \pm 3$ & $12 \pm 6.5$ \\
\hline MCF10A & Breast (Normal) ${ }^{c}$ & $18 \pm 5$ & $42 \pm 9$ & $20 \pm 4$ & $66 \pm 7$ & $67 \pm 17$ \\
\hline A2780 & Ovarian & $33 \pm 6$ & $66 \pm 4$ & $47 \pm 7$ & $89 \pm 1$ & $28 \pm 2.6$ \\
\hline $\mathrm{H} 460$ & Lung & $29 \pm 4$ & $55 \pm 2$ & $34 \pm 4$ & $57 \pm 3$ & $81 \pm 4.1$ \\
\hline A431 & Skin & $36 \pm 1$ & $57 \pm 2$ & $27 \pm 2$ & $85 \pm 3$ & $50 \pm 4.2$ \\
\hline Du145 & Prostate & $43 \pm 4$ & $66 \pm 3$ & $41 \pm 4$ & $83 \pm 3$ & $36 \pm 13$ \\
\hline BE2-C & Neuroblastoma & $39 \pm 0.5$ & $54 \pm 4$ & $32 \pm 5$ & $53 \pm 4$ & $91 \pm 12$ \\
\hline MiaPaCa2 & Pancreas & $24 \pm 5$ & $50 \pm 4$ & $28 \pm 1$ & $70 \pm 3$ & $66 \pm 5.2$ \\
\hline
\end{tabular}

aPercentage growth inhibition in response to $100 \mu \mathrm{g} / \mathrm{mL}$ of extract, the higher the value the greater the inhibition.

${ }^{\mathrm{b}}$ Concentration $(\mu \mathrm{g} / \mathrm{mL})$ that inhibits cell growth by $50 \%$; the lower the value the greater the inhibition.

'Breast cell line derived from normal non-tumour derived tissue

Table 4: Cell growth inhibition of $S$. spinescens extract across various cell lines.

$\left(\mathrm{R}^{2}=0.79\right)$ and FRAP $\left(\mathrm{R}^{2}=0.71\right)$, indicating that TPC contributed to $85 \%, 81 \%, 79 \%$ and $71 \%$ of total antioxidant, free radical scavenging capacity of SC, respectively. These findings were in agreement with previous studies [18-20] and indicated that antioxidant capacity of SC is mainly derived from the presence of phenolics.

\section{Assessment of growth inhibition of crude S. spinescens extracts on cancer cells in vitro}

Many plant derived mono and poly-phenolic compounds have been shown to possess growth inhibitory activity [4] Evaluation of SC extracts showed inhibition of cell growth across the panel of cell lines with varying efficacy (Table 4). At $100 \mu \mathrm{g} / \mathrm{mL}$ the crude SC acetone extract demonstrated the greatest growth inhibition against all cell lines $(41-83 \%)$, when compared to the aqueous (18-44\%), methanol (34-68\%), and ethanol (22-65\%) extracts. Subsequent dose response analyses showed the acetone extract exhibited the greatest effects against ovarian (A2780: $\mathrm{GI}_{50} 28 \pm 2.6 \mu \mathrm{g} / \mathrm{mL}$ ), glioblastoma (SJ-G2: $\mathrm{GI}_{50} 20 \pm 9.5 \mu \mathrm{g} / \mathrm{mL}$ ) prostate (Du145: $\mathrm{GI}_{50} 36 \pm 13 \mu \mathrm{g} / \mathrm{mL}$ ), and breast (MCF-7: GI $_{50} 12 \pm 6.5 \mu \mathrm{g} / \mathrm{mL}$ ) cancer cells. Moreover, the SC extract was up to 9-fold more potent at inhibiting growth in the breast cancer cells than in those derived from other tumour types $\left(\mathrm{GI}_{50} 20-110 \mu \mathrm{g} /\right.$ $\mathrm{mL}$ ) and was 6-fold more potent in breast cancer cells than in normal breast cells $(67 \mu \mathrm{g} / \mathrm{mL})$.

Approximately $75 \%$ of all breast cancers are hormonally dependent and the MCF7 cell line is representative of such estrogen-dependent breast carcinomas [21,22]. Anti-estrogen therapy targeting the synthesis of estrogen and the estrogen receptor are the mainstay treatment options for hormonally dependant breast cancers. Various plant-derived polyphenolic phytoestrogens are known to alter estrogen dependent signalling pathways and reduce cancer growth [23]. Potentially the selectivity of SC extract towards estrogen-responsive breast cancer cells may lie within the extracted TPC compounds. Our data underscore the need to further purify and investigate SC for its anti-cancer activity.

\section{Conclusions}

Extraction conditions significantly affected total phenolic content, antioxidant capacity and anti-cancer properties of Scaevola spinescens. Extraction conditions using water, a common solvent used for extraction of $S$. spinescens, majorly influenced extraction efficiency of the total phenolic content. The optimal conditions for extraction of TPC using water were $80^{\circ} \mathrm{C}, 15 \mathrm{~min}$ and water-to-SC ratio of $20: 1$ $\mathrm{mL} / \mathrm{g}$. Nevertheless while water is a safe, inexpensive and accessible solvent, it was found to be less effective for the extraction of TPC than common organic solvents. In addition, water extract had lower antioxidant capacity and anti-cancer activity than organic solvent extracts. Among the three solvents tested, acetone was overall the most effective for generating extracts with the highest bioactive yield, greater antioxidant activity and anti-cancer effect. In summary, S. spinescens possesses significant bioactive compound levels, and further studies are recommended for the identification of key phenolic compounds, as well as their anti-cancer mechanisms.

\section{Acknowledgement}

The authors would like to thank Ms Jeanie Crago for providing the photographs and samples of Scaevola spinescens (Goodeniaceae). We acknowledge the following funding support: Ramaciotti Foundation (ES2012/0104); Cancer Australia and Cure Cancer Australia Foundation (1033781), and the Hunter Cancer Research Alliance (HCRA).

\section{References}

1. Ghisalberti EL (2004) The Goodeniaceae. See comment in PubMed Commons below Fitoterapia 75: 429-446.

2. Kerr PG, Longmore RB, Betts TJ (1996) Myricadiol and other taraxerenes from Scaevola spinescens. Planta Med 62: 519-522.

3. Visioli F, De La Lastra CA, Andres-Lacueva C, Aviram M, Calhau C, et al (2011) Polyphenols and human health: a prospectus. Crit Rev Food Sci Nutr 51: 524-546.

4. Vuong QV, Hirun S1, Phillips PA2, Chuen TL1, Bowyer MC1, et al. (2014) Fruit-derived phenolic compounds and pancreatic cancer: perspectives from Australian native fruits. J Ethnopharmacol 152: 227-242.

5. Vuong QV, Stathopoulos CE, Nguyen MH, Golding JB, Roach PD (2011) Isolation of Green Tea Catechins and Their Utilization in the Food Industry. Food Reviews International 27: 227-247.

6. Vuong QV, Stathopoulos CE, Golding JB, Nguyen MH, Roach PD (2011) Optimum conditions for the water extraction of L-theanine from green tea. J Sep Sci 34: 2468-2474.

7. Vuong QV, Hirun S, Roach PD, Bowyer MC, Phillips PA, et al. (2013) Effect of extraction conditions on total phenolic compounds and antioxidant activities of Carica papaya leaf aqueous extracts. Journal of Herbal Medicine 3: 104-111.

8. Thaipong K, Boonprakob U, Crosby K, Cisneros-Zevallos L, Hawkins Byrne D (2006). Comparison of ABTS, DPPH, FRAP, and ORAC assays for estimating antioxidant activity from guava fruit extracts. Journal of Food Composition and Analysis 19: 669-675. 
Citation: Vuong QV, Sadeqzadeh E, Hirun S, Goldsmith CD, Zammitt N, et al. (2014) Phenolic Compounds, Antioxidant and Anti-Cancer Properties of the Australian Maroon Bush Scaevola spinescens (Goodeniaceae). J Bioanal Biomed S12: 002. doi:10.4172/1948-593X.S12-002

9. Apak R, Güclü K, Ozyürek M, Karademir SE (2004). Novel total antioxidant capacity index for dietary polyphenols and vitamins $C$ and $E$, using their cupric ion reducing capability in the presence of neocuproine: CUPRAC Method. Journal of Agricultural and Food Chemistry 52: 7970-7981.

10. Deane FM, O'Sullivan EC, Maguire AR, Gilbert J, Sakoff JA, et al. (2013) Synthesis and evaluation of novel ellipticines as potential anti-cancer agents. Org Biomol Chem 11: 1334-1344.

11. Box GEP, Behnken DW (1960) Some new three level designs for the study of quantitative variables. Technometrics 2: 455-475.

12. ML Maguer, J Shi (2002) Functional foods: Biochemical and processing aspects. Boca Raton: CRC Press pp. 331-366.

13. Michiels JA, Kevers C, Pincemail J, Defraigne JO, Dommes J (2012) Extraction conditions can greatly influence antioxidant capacity assays in plant food matrices. Food Chemistry 130: 986-993.

14. Tomsone L, Kruma Z, Galoburda R (2012) Comparison of different solvents and extraction methods for isolation of phenolic compounds from Horseradish roots (Armoracia rusticana). World Academy of Science Engineering and Technology 6: 1164-1169.

15. Ding Z (1999) Studies on extraction and isolation of flavonoids from Ginkgo leaves. Journal of Food Quality 22: 693-700.

16. Tan MC, Tan CP, Ho CW (2013) Effects of extraction solvent system, time and temperature on total phenolic content of henna (Lawsonia inermis) stems. International Food Research Journal 20: 3117-3123.
17. Pisoschi AM, Negulescu GP (2011) Methods for total antioxidant activity determination: A review. Biochemistry and Analitical Biochemistry 1: 1-5.

18. Alu'datt MH, Alli I, Ereifej K, Alhamad MN, Alsaad A, et al. (2011) Optimisation and characterisation of various extraction conditions of phenolic compounds and antioxidant activity in olive seeds. Nat Prod Res 25: 876-889.

19. Li Y, Guo C, Yang J, Wei J, Xu J, et al. (2006) Evaluation of antioxidant properties of pomegranate peel extract in comparison with pomegranate pulp extract. Food Chemistry 96: 254-260.

20. Pinelo M, Rubilar M, Jerez M, Sineiro J, Núñez MJ (2005) Effect of solvent temperature, and solvent-to-solid ratio on the total phenolic content and antiradical activity of extracts from different components of grape pomace. $J$ Agric Food Chem 53: 2111-2117.

21. Harvey JM, Clark GM, Osborne CK, Allred DC (1999) Estrogen receptor status by immunohistochemistry is superior to the ligand-binding assay for predicting response to adjuvant endocrine therapy in breast cancer. J Clin Oncol 17: 1474-1481.

22. Musgrove EA1, Sutherland RL (2009) Biological determinants of endocrine resistance in breast cancer. See comment in PubMed Commons below Nat Rev Cancer 9: 631-643.

23. Liu MM, Huang Y, Wang J (2012) Developing phytoestrogens for breast cancer prevention. Anticancer Agents Med Chem 12: 1306-1313.
This article was originally published in a special issue, Development of Phyłochemicals as Drugs handled by Editor. Dr. Erik de Leeuw, University of Maryland, USA 